\title{
Article \\ An Exploratory Bibliometric Analysis of the Birth and Emergence of Industry 5.0
}

\author{
Dag Øivind Madsen ${ }^{1, *(D)}$ and Terje Berg ${ }^{2}$ \\ 1 Department of Business, Marketing and Law, School of Business, University of South-Eastern Norway, \\ Bredalsveien 14, 3511 Hønefoss, Norway \\ 2 NTNU Business School, Norwegian University of Science and Technology, Klæbuveien 72, \\ 7491 Trondheim, Norway; terje.berg@ntnu.no \\ * Correspondence: dagmadsen@gmail.com
}

Citation: Madsen, D.Ø.; Berg, T. An Exploratory Bibliometric Analysis of the Birth and Emergence of Industry 5.0. Appl. Syst. Innov. 2021, 4, 87. https://doi.org/10.3390/asi4040087

Academic Editors: Mario Di Nardo and Haoxuan Yu

Received: 27 September 2021

Accepted: 1 November 2021

Published: 4 November 2021

Publisher's Note: MDPI stays neutral with regard to jurisdictional claims in published maps and institutional affiliations.

Copyright: (c) 2021 by the authors. Licensee MDPI, Basel, Switzerland. This article is an open access article distributed under the terms and conditions of the Creative Commons Attribution (CC BY) license (https:// creativecommons.org/licenses/by/ $4.0 /)$.

\begin{abstract}
This study provides an exploratory bibliometric analysis of the emerging literature on Industry 5.0, which is a new visionary concept on the future of industry. Industry 5.0 has in recent years begun to attract the interest of both practitioners and academics, but this new field can still be considered embryonic and not well documented. Therefore, this study aims to map the field and provide a preliminary picture of the emergence and status of the scientific literature on Industry 5.0. Bibliometric data covering the period from 2015 to 2021 were extracted from the Scopus database. Bibliometric analyses of overall publication volume and growth trajectory, influential documents, authors, sources and countries are performed. The exploratory analysis provides a preliminary overview of the birth and emergence of this new research area. The results are discussed in relation to theories on the emergence and evolution of new management concepts. The article closes with some speculations about the future trajectory of Industry 5.0.
\end{abstract}

Keywords: Industry 5.0; Industry 4.0; bibliometrics; scopus; evolution; future trajectory

\section{Introduction}

Industry 5.0 is a new visionary concept that seeks to make industry more "sustainable, human-centric and resilient" [1]. As Di Nardo and Yu [2] (p. 1) point out, "while a significant number of companies around the world are still trying to adapt to Industry 4.0, the discussion about Industry 5.0 has already begun." The origins of Industry 5.0 can be traced back to social media posts from the mid-2010s [3-5]. However, the concept quickly attracted the interest of academic researchers as well [6-10].

In this study, we perform an exploratory analysis of the emerging literature on Industry 5.0. While there have been many bibliometric analyses of the much larger Industry 4.0 literature, e.g., [11-18], to the best of our knowledge, no similar bibliometric analysis has so far been conducted on Industry 5.0. It is our view that such a study can provide a preliminary picture and overview of the emergence and status of the scientific literature on Industry 5.0.

Management concepts, such as Industry 5.0, are, by definition, abstract ideas generalized from practices. Often, they constitute the core of a scholarly field, its corpus. By mapping the field of Industry 5.0, we aim to sketch a picture of the current research front. The purpose of this quantitative examination is to make a vague and fluid concept more tangible. More broadly, the analysis can potentially cast light on the processes and dynamics that take place in the early phase of establishing scientific literature and discourse around new management concepts. Therefore, the study can also possibly contribute to our understanding of the birth and emergence of management concepts and ideas [19-21].

The rest of the paper is structured as follows. Section 2 provides a brief background to the concepts of Industry 4.0 and Industry 5.0. Section 3 provides an overview of the bibliometric methods and data. Section 4 presents the results from the bibliometric 
analysis. Section 5 provides a brief discussion of the findings in relation to theories about management concepts. Finally, Section 6 concludes the paper by highlighting contributions, limitations and ideas for future research on Industry 5.0.

\section{Background}

This section provides a brief historical background to the concepts of Industry 4.0 and Industry 5.0 and a discussion of their main similarities and differences.

\subsection{Industry 4.0}

The concept of Industry 4.0 was introduced at the 2011 Hannover Fair [22,23]. Industry 4.0 generally refers to the fourth industrial revolution in manufacturing. The consulting firm McKinsey \& Company highlights that "Industry 4.0 is more than just a flashy catchphrase. A confluence of trends and technologies promises to reshape the way things are made" [24] (p. 1). These trends and technologies include robotics, artificial intelligence, virtual reality, blockchain, big data analytics and the Internet of Things [25]. According to proponents of Industry 4.0, these new technologies can enable the transformation and automation of manufacturing processes and increase operational efficiency and organizational performance [24-26].

In the decade since its introduction, the Industry 4.0 concept has attracted considerable attention both in academia and in the business world. The literature on Industry 4.0 has grown exponentially $[15,17,27,28]$ and many studies have shown that Industry 4.0 has become a popular and influential management trend across a wide range of industries and in many parts of the world [23,29-35]. While Industry 4.0 started in manufacturing, it has become a much broader and universal approach, applied and adapted to a wide range of contexts such as healthcare (Healthcare 4.0), auditing (Auditing 4.0), and tourism/hospitality (Tourism 4.0) $[23,29,36]$.

Despite its widespread popularity, the Industry 4.0 concept is not without critics. Different authors have already started to criticize and question different aspects of Industry 4.0. For example, some critics have suggested that the ideas behind Industry 4.0 are not new and that similar approaches have been circulating in academic research for quite some time [28,37]. Others have criticized the technocratic nature of the concept and its strong emphasis on technology and automation see, e.g., [38-40].

Therefore, it is not surprising that a potential successor to Industry 4.0 has appeared in social media discourse and academic journals. As early as in 2014, Lasi et al. [41] observed that the label Industry 4.0 is "reminiscence of software versioning." As Madsen [23] noted, using a version number in the label implies that the last word is not said, and it invites others to propose new versions (e.g., 5.0 or 6.0). For example, Di Nardo and Yu [2] suggest that Industry 5.0 could be a "prelude to the sixth industrial revolution."

\subsection{Industry 5.0}

The nascent concept of Industry 5.0 has attracted increasing amounts of attention in the last few years $[2-5,42,43]$. Several authors note that Industry 5.0 has roots in the Industry 4.0 paradigm. For example, Özdemir and Hekim [8] (pp. 71-72) see it "as an evolutionary, incremental (but critically necessary) advancement that builds on the concept and practices of Industry 4.0." The European Commission [1] (pp. 3-4) argues that Industry 5.0 "complements the existing 'Industry $4.0^{\prime}$ paradigm by having research and innovation drive the transition to a sustainable, human-centric and resilient European industry. It moves the focus from solely shareholder value to stakeholder value, for all concerned." In a similar vein, several authors have suggested that Industry 5.0 is better able to take into account the human-machine dimension $[3,4,6-8,10,44-47]$.

However, since Industry 5.0 is a new concept, there is currently little consensus on how the concept should be defined. Instead, different authors have different opinions and ideas about the concept. For example, Rada [3,4] primarily highlights the role of sustainability, while others focus on taking a human-centric approach [9] and focus mostly on how 
humans can work alongside robots [7]. As noted, The European Commission has also shaped the discourse around Industry 5.0 by describing and defining the concept $[1,48]$.

\subsection{Similarities and Differences}

There are both similarities and differences between the two concepts. In terms of similarities, two concepts can both be considered management concepts, since they offer what Benders and Verlaar [49] (p. 758) call "prescriptive, more or less coherent views on management". As suggested by Braam et al. [50] (p. 868), such management concepts "may play an important role in shaping contemporary organizational processes, structures and organizational behavior."

A key characteristic of management concepts is their ideational nature, making them ambiguous and open to interpretation [51,52]. Both Industry 4.0 and Industry 5.0 score highly when it comes to room for interpretation, since they are arguably somewhat elusive and hard to grasp. In the case of Industry 4.0, it has been noted that there is some "conceptual confusion" in organizational practice [53]. For example, there are more than 100 different definitions of the concept in the literature [54], and there is also a high number of Industry 4.0-related neologisms (e.g., Work 4.0) [23,29]. Therefore, it should not be surprising that the concept has different meanings [55] and is perceived and understood differently by different actors across contexts.

A similar trend can also be seen as emerging in the case of Industry 5.0. Different authors have different takes and views on what the Industry 5.0 concept should be about $[3,5,43]$. Moreover, Industry 5.0-related neologisms such as Supply Chain 5.0 and Hospitality 5.0 have already been proposed [56,57].

A key difference between the two concepts relates to how they are presented and portrayed differently. In the case of Industry 4.0, supporting actors, such as consulting firms, highlight the potential economic benefits of adopting new Industry 4.0-related trends and technologies. It is typically argued that automation will lead to increased productivity and growth $[24,26]$. The Industry 4.0 concept is also heavily technology infused and, according to Kopp et al. [58], it can be considered a "technology-centered vision" of industry. In contrast, Industry 5.0 is positioned as considerably more human centric $[1,9,48,59]$.

The two concepts also differ somewhat in terms of their vision of the future. Overall, it can be argued that Industry 4.0 paints a more optimistic picture of the future of industry [23]. In the words of Johansson et al. [60] (p. 282), the German vision of Industry 4.0 "paints a bright picture of the future industry". Generally, it is envisioned that new technologies will enable automation, which will positively affect productivity and profitability. In contrast, proponents of Industry 5.0 make different appeals, focusing heavily on issues of sustainability, resilience, and human-robot interaction. In the case of Industry 5.0, it is often pointed out that embarking on this journey can be costly in the short run in order to reach the long-term objectives of sustainability and resilience [61].

\section{Methods and Data}

Bibliometric methods are statistical analyses used to examine scientific publications and can be used to evaluate and assess scholarly production in a particular field [62]. In recent years, it has become a widely used research method in business and management studies, and there are several "how to" guides available [63,64].

Bibliometric methods are also often used to study the lifecycles and evolution of management concepts and ideas [65,66]. As Strang and Wittrock [65] (p. 94) point out, "bibliometric studies map the interest in management ideas over time by counting numbers of publications on a given topic as well as classifying these into various categories". While bibliometric methods are often criticized for providing little insight into how management concepts are actually used in organizations [67], they can provide useful insights into the macro-level evolution of management concepts [65]. Since the purpose of this paper is to obtain a birds-eye overview of the birth and emergence of the Industry 5.0 concept as a 
research area and not its micro-level implementation in a particular organization or industry, employing bibliometric methods is deemed to be an appropriate methodological choice.

The bibliometric data used in this study were extracted from the Scopus database (www.scopus.com, accessed on: 13 September 2021). There are several arguments for using Scopus, such as a wider coverage in terms of sources than Web of Science $[68,69]$. Wide coverage is an important consideration in the context of Industry 5.0 since early publications about a new concept sometimes may be published outside of the core or "top" journals in a field. Zupic and Čater [64] (p. 42) also note that "broader coverage is useful for mapping smaller research areas." Although Web of Science has coverage that goes back further than Scopus [69], this is not a relevant consideration in this particular study since the history of Industry 5.0 is short.

A decision also had to be made regarding the time period for the analysis. Although there is some disagreement about exactly when, where and who introduced and coined the Industry 5.0 term [2-5], the earliest Scopus-indexed publication is from 2016 [6]. Therefore, it was deemed appropriate to use 2015-2021 as a period for analysis.

When it comes to the choice of search terms, we decided to only use "Industry 5.0". Moreover, it was decided to search for documents mentioning "Industry 5.0" in the abstract, title or keywords, with the aim of not excluding any possibly relevant publications. This is an important consideration given that Industry 5.0 is a new concept and the available body of literature is small. Although previous analyses of Industry 4.0 have used a broader set of search terms, including related terms such as "smart manufacturing" and "smart factories" [70,71], we decided that the inclusion of other related terms would yield many publications not focusing on Industry 5.0. Moreover, since Industry 5.0 is still an emerging and developing term, it is unclear what other key terms or synonyms are used.

Academic literature may be divided into three categories: conventional wisdom (textbooks), scientific literature (scientific journals) and practitioner literature (professionally oriented journals and popularized science books). All three categories are relevant in the context of management concepts since suppliers of concepts write about them in textbooks, conduct academic studies about the use and effects of concepts and present them in a more accessible and popularized way to a managerial audience [72-74]. Our use of the Scopus database as a data source means that we are primarily able to capture discourse about Industry 5.0 in scientific journals and only to a limited extent practitioner-oriented literature.

Since the total volume of publications regarding Industry 5.0 is currently low, we decided to be as inclusive as possible. It is likely that much of the discourse in the early phase may have taken place outside of journals, such as in conference proceedings. Many of the researchers working on Industry 5.0 and similar topics are engineers and computer scientists. In these two scientific fields, researchers tend to publish more in conference proceedings than those in, for example, business and management. For example, Goodrum et al. [75] (pp. 661-662) note that in computer-related fields "some conference proceedings are seen as more timely, more cutting edge and more strictly refereed than some journals". Therefore, due to the newness of the topic and the limited number of publications, we deemed it appropriate to use an inclusive approach that takes into account publications across all research areas, source types and languages.

The various considerations and choices are summarized in Table 1 . As can be seen, the following search query was used: TITLE-ABS-KEY ("Industry 5.0") AND PUBYEAR > 2014. In other words, the search was for documents with the term "Industry 5.0" in the title, abstract or keywords between 2015 and 2021. 
Table 1. Overview of search procedure (source: own elaboration).

\begin{tabular}{cc}
\hline Database & Scopus \\
\hline Search query & TITLE-ABS-KEY (“Industry 5.0”) AND PUBYEAR > 2014 \\
\hline Time period & 2015-2021 \\
\hline Date of query & 13 September 2021 \\
\hline Categories & All \\
\hline Sources & All \\
\hline Languages & Any \\
\hline Number of documents & 92 \\
\hline
\end{tabular}

Finally, the bibliometric data from Scopus were exported to the software package VOSviewer [76], which we then used to find the most cited publications, authors, sources and countries.

\section{Results}

This section presents the results of the bibliometric analyses. It starts off by examining the publication types and the research areas covered. Then the overall trend in terms of volume and growth trajectory is analyzed, followed by analyses of the most influential documents, sources, authors and countries in terms of total citations.

\subsection{Document Types}

As shown in Figure 1, most of the 92 documents are either journal articles (51) or conference papers (31). Only 10 of the documents are other types of publications (e.g., book chapters).

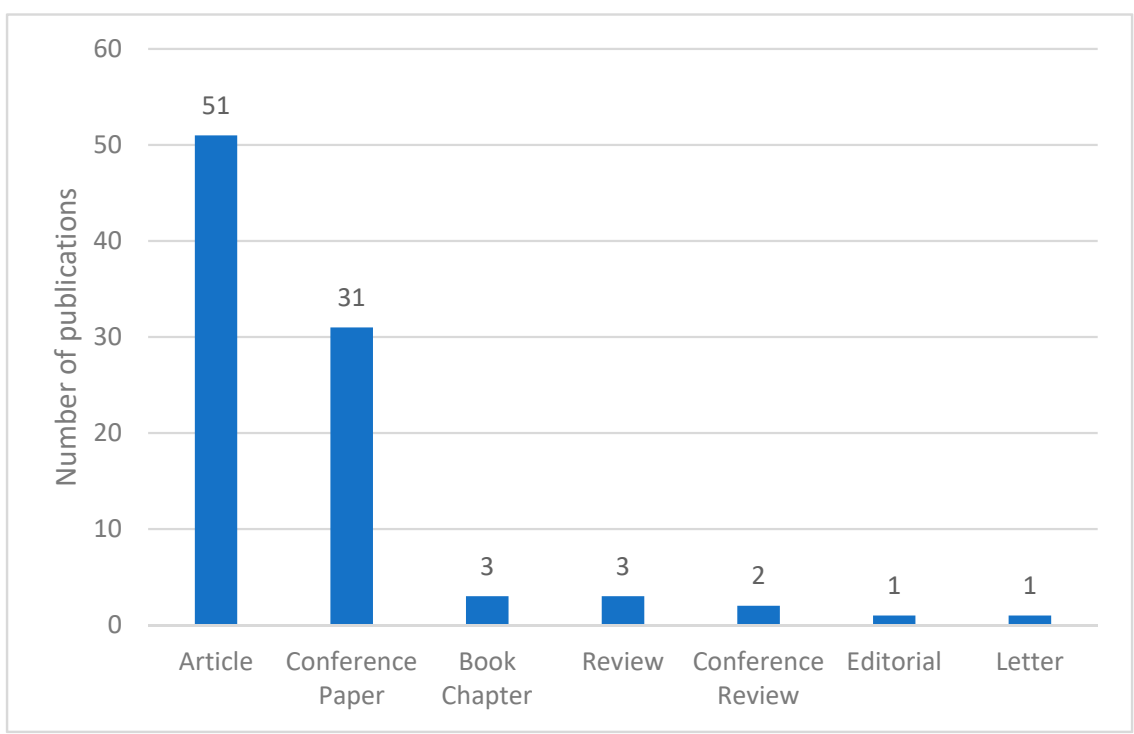

Figure 1. Distribution of document types (source: own elaboration using data from Scopus).

\subsection{Subject Areas}

Figure 2 shows that publications about Industry 5.0 span a wide and diverse range of subject and research areas. The majority of the publications belong to engineering (45); computer science (40); business, management and accounting (17); social sciences (14) and mathematics (13). In a bibliometric study of Industry 4.0 in the Web of Science, Janik and Ryszko [77] found a relatively similar pattern, with engineering and computer science being the most dominant categories, with $58 \%$ and $33 \%$ of the records, respectively. 


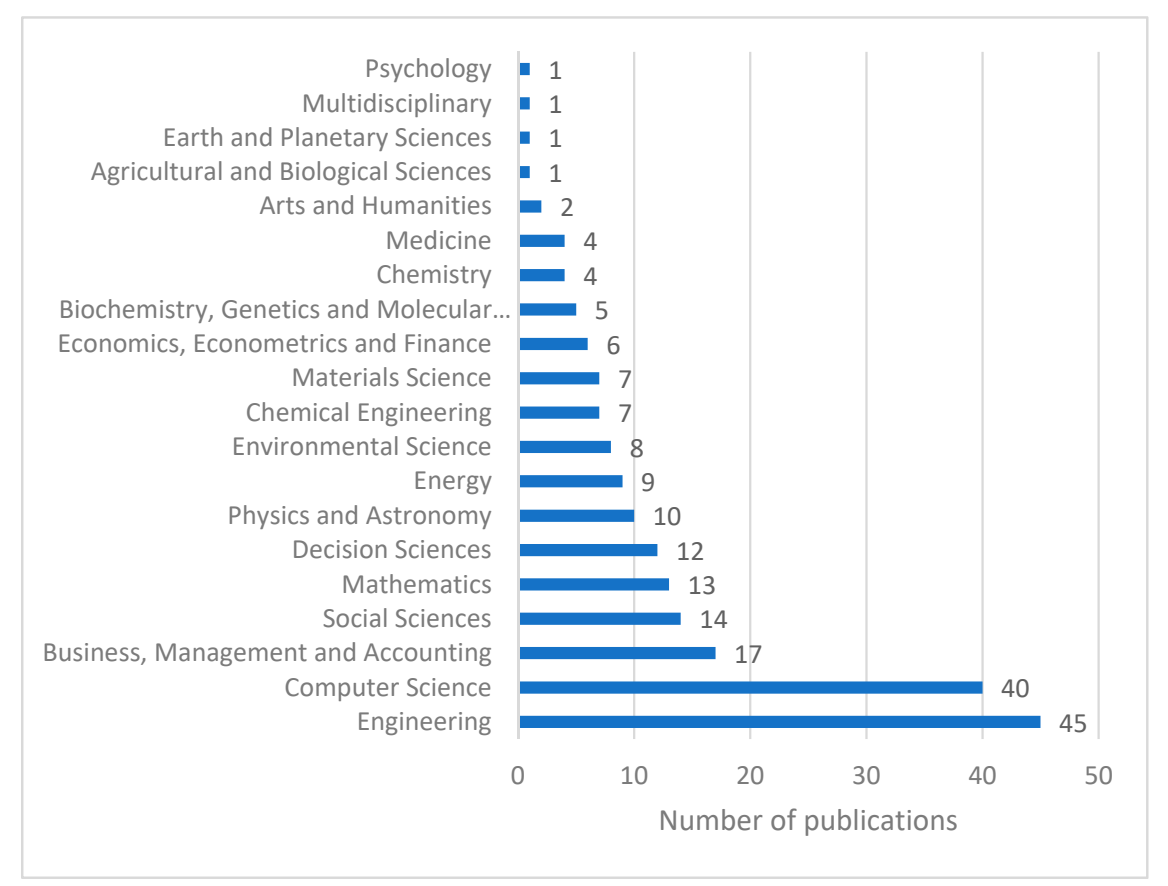

Figure 2. Distribution of publications across different subject areas (source: own elaboration using data from Scopus). It should be noted that some publications are classified as belonging to more than one subject area.

\subsection{Volume and Growth Trajectory}

Figure 3 displays the volume and growth trajectory of research related to Industry 5.0. The overall trend shows an increase in the number of publications per year. As can be seen from the figure, the first article was published in 2016. The volume of publications started picking up in 2019 and since then has continued to increase. It should be noted that the figure only contains partial data for the year 2021 (only eight full months). As of September 2021 , the number of publications had already exceeded the 2020 total. Therefore, it is likely that this number will increase considerably.

\subsection{Most Influential Documents}

Table 2 provides an overview of the most cited publications on Industry 5.0. The most cited article is the article by Özdemir and Hekim [8] called "Birth of industry 5.0: Making sense of big data with artificial intelligence, 'the internet of things' and next-generation technology policy" which has been cited 90 times. In this article, the authors point out that Industry 5.0 "is about building complex and hyperconnected digital networks without compromising long-term safety and sustainability of an innovation ecosystem and its constituents" (p. 74). In second place is "Industry 5.0-A human-centric solution" written by Nahavandi [9], which has been cited 65 times. In this conceptual article, Nahavandi [9] (p. 1) describes Industry 5.0 as a situation "where robots are intertwined with the human brain and work as collaborator instead of competitor". 


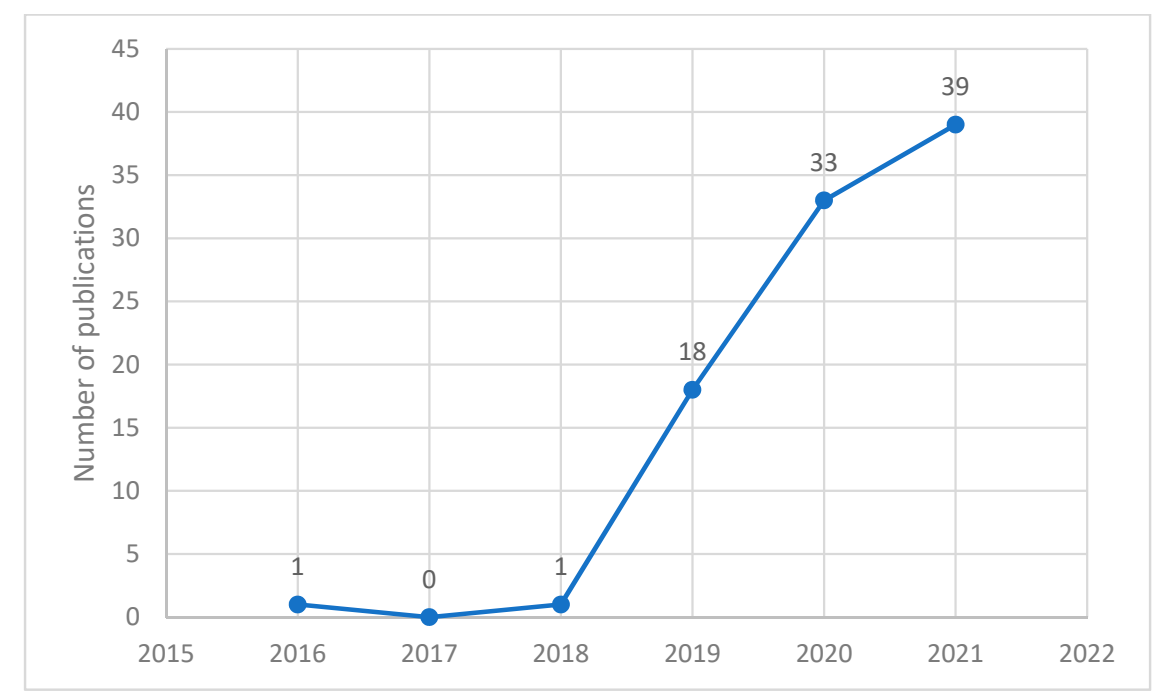

Figure 3. Volume and growth trajectory of Industry 5.0 research in the Scopus database 2015-2021 (source: own elaboration using data from Scopus).

In third place is "A novel intelligent medical decision support model based on soft computing and IoT" by Abdel-Basset et al. [78]. The authors focus on next-generation Internet of Things systems, which they claim are important in the development of Industry 5.0. In fourth place follows the article "Industry 5.0 and human-robot co-working" by Demir, Döven and Sezen [7]. In this article, the authors discuss two visions of Industry 5.0; one focusing on human-robot co-working and creating a smart society, and another focusing on bioeconomy to achieve greater sustainability. They also identify and discuss issues and challenges related to human-robot co-working. Finally, the article by Sachsenmeier [6] (ranked fifth) is a discussion article that focuses on the role of bionics and synthetic biology in the industry of the future. According to Sachsenmeier [6] (p. 225) synthetic biology "will be as pervasive and transformative in the next 50 years as digitization and the Internet are today".

Table 2. Most cited publications in the field of Industry 5.0 in the period 2015-2021 (source: VOSviewer using data from Scopus).

\begin{tabular}{|c|c|c|c|c|}
\hline Rank & Author(s) & Title & Source Title & Times Cited \\
\hline 1 & Özdemir and Hekim [8] & $\begin{array}{l}\text { Birth of industry 5.0: Making sense of big data with } \\
\text { artificial intelligence, "the internet of things" and } \\
\text { next-generation technology policy }\end{array}$ & $\begin{array}{l}\text { Omics: a journal of integrative biology, } \\
\qquad 22(1), 65-76\end{array}$ & 90 \\
\hline 2 & Nahavandi [9] & Industry 5.0-A human-centric solution & Sustainability, 11(16), 4371 & 65 \\
\hline 3 & $\begin{array}{l}\text { Abdel-Basset, Manogaran, } \\
\text { Gamal and Chang [78] }\end{array}$ & $\begin{array}{l}\text { A novel intelligent medical decision support model } \\
\text { based on soft computing and IoT }\end{array}$ & $\begin{array}{l}\text { IEEE Internet of Things Journal, } \\
7(5), 4160-4170\end{array}$ & 34 \\
\hline 4 & $\begin{array}{l}\text { Demir, Döven } \\
\text { and Sezen [7] }\end{array}$ & Industry 5.0 and human-robot co-working & Procedia Computer Science, 158, 688-695 & 29 \\
\hline 5 & Sachsenmeier [6] & $\begin{array}{c}\text { Industry } 5.0 \text { - the relevance and implications of } \\
\text { bionics and synthetic biology }\end{array}$ & Engineering, 2(2), 225-229 & 26 \\
\hline 6 & Bednar and Welch [79] & $\begin{array}{l}\text { Socio-technical perspectives on smart working: } \\
\text { Creating meaningful and sustainable systems }\end{array}$ & $\begin{array}{l}\text { Information Systems Frontiers, } \\
\text { 22(2), 281-298 }\end{array}$ & 22 \\
\hline 7 & $\begin{array}{l}\text { Javaid, Haleem, Singh, } \\
\text { Haq, Raina and Suman [10] }\end{array}$ & Industry 5.0: Potential applications in COVID-19 & $\begin{array}{l}\text { Journal of Industrial Integration } \\
\text { and Management }\end{array}$ & 17 \\
\hline 8 & $\begin{array}{l}\text { Longo, Padovano } \\
\text { and Umbrello [59] }\end{array}$ & $\begin{array}{l}\text { Value-oriented and ethical technology engineering in } \\
\text { industry 5.0: a human-centric perspective for the } \\
\text { design of the factory of the future }\end{array}$ & Applied Sciences, 10(12), 4182 & 16 \\
\hline 9 & Welfare et al. [80] & $\begin{array}{l}\text { Consider the human work experience when } \\
\text { integrating robotics in the workplace }\end{array}$ & $\begin{array}{l}2019 \text { 14th ACM/IEEE International } \\
\text { Conference on Human-robot Interaction } \\
\text { (HRI) (pp. 75-84). IEEE }\end{array}$ & 16 \\
\hline 10 & Wang et al. [81] & $\begin{array}{c}\text { Walrasian equilibrium-based multiobjective } \\
\text { optimization for task allocation in } \\
\text { mobile crowdsourcing }\end{array}$ & $\begin{array}{l}\text { IEEE Transactions on Computational } \\
\text { Social Systems, 7(4), 1033-1046 }\end{array}$ & 14 \\
\hline
\end{tabular}




\subsection{Most Influential Sources}

Table 3 displays the most influential sources in Industry 5.0 research. As can be seen from the table, these sources are a mix of journals and conference proceedings. The relative importance of conference proceedings is not surprising given that much of the research is conducted in the fields of engineering and computer science, two fields that tend to publish in conference proceedings to a greater extent than, for example, business and management researchers. It is also notable that there are several open-access journals. Researchers in a new field such as Industry 5.0 may seek out journals with faster-moving, peer-review processes, especially in the early phase where authors race to become perceived as experts and authorities in a new field.

Table 3. Most influential sources (source: VOSviewer using data from Scopus).

\begin{tabular}{lcc}
\hline \multicolumn{1}{c}{ Source } & Documents & Citations \\
\hline Omics: A Journal of Integrative Biology & 2 & 90 \\
\hline Sustainability & 4 & 67 \\
\hline IEEE Internet of Things Journal & 1 & 34 \\
\hline Journal of Industrial Integration and Management & 2 & 29 \\
\hline Procedia Computer Science & 1 & 29 \\
\hline Engineering & 1 & 26 \\
\hline Information Systems Frontiers & 1 & 22 \\
\hline Applied Sciences & 1 & 16 \\
\hline $\begin{array}{l}\text { ACM/IEEE International Conference on Human-Robot } \\
\text { Interaction }\end{array}$ & 1 & 16 \\
\hline Journal of the Knowledge Economy & 5 & 15 \\
\hline IEEE Transactions on Computational Social Systems & 1 & 14 \\
\hline Information & 1 & 10 \\
\hline Journal of Clinical Orthopaedics and Trauma & 1 & 9 \\
\hline $\begin{array}{l}\text { Conference Proceedings of 2019 10th International Conference } \\
\text { on Dependable Systems, Services and Technologies, DESSERT }\end{array}$ & 1 & 9 \\
\hline International Journal of Supply Chain Management & 2 & 9 \\
\hline
\end{tabular}

The most influential source is Omics: A Journal of Integrative Biology, which covers areas such as bioinformatics and computational biology. The journal has published the influential article by Özdemir and Hekim [8] presented in the previous section. The second most influential journal is Sustainability, which has published four articles dealing with Industry 5.0, including the second-most cited article by Nahavandi [9].

\subsection{Most Influential Authors}

Table 4 provides an overview of the most influential authors with contributions to the scientific literature about Industry 5.0. The authors are ranked by citations rather than the number of documents. As can be seen from the table, Özdemir, $\mathrm{V}$ and Hekim, $\mathrm{N}$ are the most influential authors with two documents and 90 citations. Nahavandi, $S$ is in third place with two documents and 67 citations. Haleem, A and Javaid, $\mathrm{M}$ are the most prolific authors with a total of 3 documents and 38 citations. Then follows a string of authors with between 22 and 34 citations. 
Table 4. Most influential authors (VOSviewer using data from Scopus).

\begin{tabular}{lcc}
\hline Author & Documents & Citations \\
\hline Hekim, N & 2 & 90 \\
\hline Özdemir, V & 2 & 90 \\
\hline Nahavandi, S & 2 & 67 \\
\hline Haleem, A & 3 & 38 \\
\hline Javaid, M & 3 & 38 \\
\hline Abdel-Basset, M & 1 & 34 \\
\hline Chang, V & 1 & 34 \\
\hline Gamal, A & 1 & 34 \\
\hline Manogaran, G & 1 & 34 \\
\hline Demir, K.A. & 2 & 30 \\
\hline Döven, G & 1 & 29 \\
\hline Sezen, B & 1 & 29 \\
\hline Sachsenmeier, P & 1 & 26 \\
\hline Bednar, P.M. & 1 & 22 \\
\hline Welch, C & 1 & 22 \\
\hline
\end{tabular}

\subsection{Most Influential Countries}

Table 5 provides an overview of the 10 most influential countries in the scientific literature on Industry 5.0 (minimum 20 citations). When ranked by the number of citations, India (143 citations) and Turkey (120 citations) are in first and second place, followed by the United States, China and Canada (all with $>90$ citations). The table shows that researchers from different parts of the world are publishing research on Industry 5.0. Notably, Germany does not feature in the top 10 when it comes to research on Industry 5.0. This differs from findings in bibliometric analyses of Industry 4.0, where Germany had the largest number of publications in the early phase [16].

Table 5. Most influential countries (source: VOSviewer using data from Scopus).

\begin{tabular}{ccc}
\hline Country & Documents & Citations \\
\hline India & 13 & 143 \\
\hline Turkey & 4 & 120 \\
\hline United States & 13 & 94 \\
\hline China & 8 & 93 \\
\hline Canada & 4 & 92 \\
\hline United Kingdom & 4 & 82 \\
\hline Australia & 6 & 74 \\
\hline Egypt & 1 & 34 \\
\hline Italy & 9 & 24 \\
\hline Sweden & 1 & 22 \\
\hline
\end{tabular}

\section{Discussion}

The exploratory analysis clearly shows that Industry 5.0 is a nascent research area. The first Scopus-indexed article was published in 2016, and it was not until 2019 that the publication activity started picking up. As has been suggested, different authors have different opinions and ideas about the Industry 5.0 concept [2]. This is expected since 
Industry 5.0 has roots in the Industry 4.0 concept and different authors have different views on what direction to take. Thus, in the early phase the field is in flux as different authors throw their hats in the ring and attempt to shape the thinking around the concept.

This bibliometric study shows that much of this debate around Industry 5.0 is happening in the scientific literature. Still, some thinkers are shaping the definition and discussion on Industry 5.0 using social media platforms such as LinkedIn instead of indexed journals [3-5]. In the digital age, discourse around new management concepts is increasingly taking place on social media platforms where there are few gatekeepers [82-84]. It remains to be seen to what extent these social media influencers will shape the scientific discourse around Industry 5.0 in the future.

It is, of course, difficult to forecast the future evolutionary trajectory of Industry 5.0 research. However, the overall publication trend is positive and 2021 will likely be a new peak in terms of publication volume. If we look at the evolutionary trajectory of Industry 4.0, this concept has experienced an almost exponential growth in the number of publications over a period of less than a decade [11-14,16-18].

However, it is not given that Industry 5.0 will attract the same levels of attention and popularity. One reason for this could be that, so far, fewer actors (e.g., consulting firms) promote and popularize the Industry 5.0 concept in the business world via reports and conferences than what has been seen in the case of Industry 4.0 [23]. The Industry 5.0 concept can also seem less attractive to stakeholders since they may have to accept losses in the short run to the achieve the long-term objectives of Industry 5.0 in relation to sustainability and resilience [61]. As Yordanova [61] points out, this "does not make Industry 5.0 particularly attractive for certain types of business entities for example SMEs".

The European Commission [48] argues that Industry 5.0 is "characterised by going beyond producing goods and services for profit. It shifts the focus from the shareholder value to stakeholder value and reinforces the role and the contribution of industry to society". However, it remains to be seen whether this call for organizations to emphasize stakeholders will appeal to managers. Previous research on popular management concepts has shown that managers are typically attracted to concepts that promise substantial performance improvements, e.g., cost reductions [51,85].

The proponents of Industry 5.0 do not appear to follow this playbook and instead appeal to other stakeholder-oriented considerations. It is, however, possible that the current strong emphasis on sustainability and sustainable development in the business world could outweigh narrow shareholder-focused concerns [86-88]. Much of the fundamental thinking of Industry 5.0 may also resonate with the UN's sustainable development goals (SDGs). Even in the context of Industry 4.0, researchers have discussed how the use of Industry 4.0 technologies may enable the achievement of the SDGs [89-91]. In Industry 5.0 the focus on sustainability is even more pronounced. Hence, it is possible that some of the thinking underlying Industry 5.0 may implicitly be practiced already under the umbrella of sustainable business practices. To some extent, the questions raised by proponents of Industry 5.0 are more philosophical and existential in nature. In the words of Sachsenmeier [6] (p. 229) "Industry 5.0 discussions touch on the very essence of humanity's existence, physical integrity, and relationship with nature".

\section{Conclusions}

\subsection{Concluding Comments}

This paper has provided an exploratory bibliometric analysis of the literature on Industry 5.0. Such an approach allows for developing a deeper understanding of the birth and emergence of the concept of Industry 5.0. In this way, we contribute to our understanding of a contemporary phenomenon in the business and organizational world.

The study also provides an overview and picture of the research front in the field of Industry 5.0, which can be useful for researchers considering exploring this field of research. Our bibliometric analysis provides a preliminary "reading list" in this area [64]. The analysis shows that the five most cited articles are Özdemir and Hekim [8]; Naha- 
vandi [9]; Abdel-Basset, Manogaran, Gamal and Chang [78]; Demir, Döven and Sezen [7] and Sachsenmeier [6].

Overall, our exploratory analysis has enabled the identification of the overall publication trend and the most influential documents, sources, authors and countries in research on Industry 5.0. The findings show that although the literature on Industry 5.0 is currently small, the overall publication trend indicates that this field of research is growing rapidly.

\subsection{Limitations and Future Research}

The bibliometric analyses performed in this paper should be considered exploratory and tentative. It is still very early, and there are a limited number of publications on Industry 5.0. There are also some general limitations associated with the bibliometric analyses undertaken in this study. One limitation is related to the use of the Scopus database as a data source. For example, not all academic journals are indexed in Scopus, which means some relevant studies may have been overlooked. Therefore, future studies could combine Scopus data with data from Web of Science or Google Scholar. The reliance on bibliometrics from Scopus also means that the study is heavily centered around scholarly discourse on Industry 5.0 that is published in academic journals. As researchers have pointed out, other research methods are needed to capture more managerially oriented discourse in magazines or on social media platforms [65,82,92].

Another limitation is the cross-sectional nature of this study. It only provides a static picture of the rapidly evolving field of Industry 5.0. Follow-up studies are needed to see how the influence of different documents, journals, authors and countries evolves and shifts over time. Since the total volume of Industry 5.0 publications and the total number of citations is low, it would not take much for new authors, journals or countries to leapfrog the current leaders. In future studies, researchers could conduct more longitudinally oriented analyses by analyzing different time periods to uncover changes in the structure and dynamics in the field of Industry 5.0.

This study has also focused on overall bibliometric patterns and has not provided much insight into the content of the Industry 5.0 concept and how it is presented. In future studies, researchers should carry out more in-depth studies, which can enable the identification of the various design and rhetorical elements of the Industry 5.0 concept.

Finally, our exploratory analysis indicates that Industry 5.0 will continue to grow, at least in the short term. However, it should be emphasized that it can be risky to extrapolate from the current trend. Donthu, Kumar, Mukherjee, Pandey and Lim [63] (p. 295) stress that "bibliometric studies can only offer a short-term forecast of the research field" and warn against strong assertions about its future importance and impact. It is unclear whether Industry 5.0 will ever reach the publication levels of Industry 4.0. This ultimately remains an empirical question that will have to be addressed in future studies. Research has shown that the lifecycles and trajectories of management concepts and ideas vary considerably [21,93]. Therefore, it will be interesting to follow the future evolutionary trajectory of the Industry 5.0 concept.

Author Contributions: Conceptualization, D.Ø.M.; data curation, D.Ø.M.; formal analysis, D.Ø.M. and T.B.; investigation, D.Ø.M. and T.B.; methodology, D.Ø.M. and T.B.; project administration, D.Ø.M.; resources, D.Ø.M.; software, D.Ø.M.; writing—original draft, D.Ø.M. and T.B.; writing-review and editing, D.Ø.M. and T.B. All authors have read and agreed to the published version of the manuscript.

Funding: The APC was funded by the University of South-Eastern Norway.

Institutional Review Board Statement: Not applicable.

Informed Consent Statement: Not applicable.

Data Availability Statement: Not applicable.

Conflicts of Interest: The authors declare no conflict of interest. 


\section{References}

1. European Commission. Industry 5.0: Towards a Sustainable, Human-Centric and Resilient European Industry; European Commission, Directorate-General for Research and Innovation: Luxembourg, 2021.

2. Di Nardo, M.; Yu, H. Special Issue. Industry 5.0: The prelude to the sixth industrial revolution. Appl. Syst. Innov. 2021, 4, 45. [CrossRef]

3. Rada, M. Industry 5.0 Definition. 2018. Available online: https://michael-rada.medium.com/industry-5-0-definition-6a2f992 2dc48 (accessed on 15 September 2021).

4. Rada, M. Industry 5.0-From Virtual to Physical. 2015. Available online: https://www.linkedin.com/pulse/industry-50-fromvirtual-physical-michael-rada (accessed on 15 September 2021).

5. Vollmer, M. What is Industry 5.0? 2018. Available online: https://medium.com/@marcellvollmer/what-is-industry-5-0-a36304 1a6f0a (accessed on 15 September 2021).

6. Sachsenmeier, P. Industry 5.0-The relevance and implications of bionics and synthetic biology. Engineering 2016, 2, 225-229. [CrossRef]

7. Demir, K.A.; Döven, G.; Sezen, B. Industry 5.0 and human-robot Co-working. Proc. Comput. Sci. 2019, 158, 688-695. [CrossRef]

8. Özdemir, V.; Hekim, N. Birth of industry 5.0: Making sense of big data with artificial intelligence. The Internet of things and next-generation technology policy. OMICS A J. Integr. Biol. 2018, 22, 65-76. [CrossRef]

9. Nahavandi, S. Industry 5.0-A human-centric solution. Sustainability 2019, 11, 4371. [CrossRef]

10. Javaid, M.; Haleem, A.; Singh, R.P.; Haq, M.I.U.; Raina, A.; Suman, R. Industry 5.0: Potential applications in COVID-19. J. Ind. Integr. Manag. 2020, 5, 507-530. [CrossRef]

11. Tavares-Lehmann, A.T.; Varum, C. Industry 4.0 and sustainability: A bibliometric literature review. Sustainability 2021, 13, 3493. [CrossRef]

12. Muhuri, P.K.; Shukla, A.K.; Abraham, A. Industry 4.0: A bibliometric analysis and detailed overview. Eng. Appl. Artif. Intell. 2019, 78, 218-235. [CrossRef]

13. Cobo, M.; Jürgens, B.; Herrero-Solana, V.; Martínez, M.; Herrera-Viedma, E. Industry 4.0: A perspective based on bibliometric analysis. Proc. Comput. Sci. 2018, 139, 364-371. [CrossRef]

14. Borregan-Alvarado, J.; Alvarez-Meaza, I.; Cilleruelo-Carrasco, E.; Garechana-Anacabe, G. A bibliometric analysis in industry 4.0 and advanced manufacturing: What about the sustainable supply chain? Sustainability 2020, 12, 7840. [CrossRef]

15. Mariani, M.M.; Borghi, M. Industry 4.0: A bibliometric review of its managerial intellectual structure and potential evolution in the service industries. Technol. Forecast. Soc. Change 2019, 149, 119752. [CrossRef]

16. Ahmi, A.; Elbardan, H.; Ali, R.H.R.M. Bibliometric analysis of published literature on industry 4.0. In Proceedings of the 2019 International Conference on Electronics, Information, and Communication (ICEIC), Auckland, New Zealand, 22-25 January 2019; IEEE: Piscataway, NJ, USA, 2019; pp. 1-6.

17. Trotta, D.; Garengo, P. Industry 4.0 key research topics: A bibliometric review. In Proceedings of the 2018 7th International Conference on Industrial Technology and Management (ICITM), Oxford, UK, 7-9 March 2018; IEEE: Piscataway, NJ, USA, 2018; pp. 113-117.

18. Kipper, L.M.; Furstenau, L.B.; Hoppe, D.; Frozza, R.; Iepsen, S. Scopus scientific mapping production in industry 4.0 (2011-2018): A bibliometric analysis. Int. J. Prod. Res. 2019, 58, 1605-1627. [CrossRef]

19. Abrahamson, E.; Piazza, A. The lifecycle of management ideas. In The Oxford Handbook of Management Ideas; Sturdy, A., Heusinkveld, S., Reay, T., Strang, D., Eds.; Oxford University Press: Oxford, UK, 2019; pp. $42-67$.

20. Spell, C.S. Where do management fashions come from, and how long do they stay? J. Manag. Hist. Arch. 1999, 5, 334-348. [CrossRef]

21. Pollach, I. The diffusion of management fads: A popularization perspective. J. Manag. Hist. 2021. ahead of print. [CrossRef]

22. Hirsch-Kreinsen, H. "Industry 4.0" as Promising Technology: Emergence, Semantics and Ambivalent Character; Technische Universität Dortmund: Dortmund, Germany, 2016.

23. Madsen, D.Ø. The emergence and rise of industry 4.0 viewed through the lens of management fashion theory. Adm. Sci. 2019, 9, 71. [CrossRef]

24. Baur, C.; Wee, D. Manufacturing's next act. McKinsey Q. 2015. Available online: https://timereaction.com/papers/ manufacturing_next_act.pdf (accessed on 15 August 2021).

25. Marr, B. What Is Industry 4.0? Here Is a Super Easy Explanation For Anyone. Forbes, 2 September 2018. Available online: https:/ / www.forbes.com/sites/bernardmarr/2018/09/02/what-is-industry-4-0-heres-a-super-easy-explanation-foranyone/(accessed on 15 August 2021).

26. Rüßmann, M.; Lorenz, M.; Gerbert, P.; Waldner, M.; Justus, J.; Engel, P.; Harnisch, M. Industry 4.0: The future of productivity and growth in manufacturing industries. Boston Consult. Group 2015, 9, 54-89.

27. Alcácer, V.; Machado, V. Scanning the industry 4.0: A literature review on technologies for manufacturing systems. Eng. Sci. Technol. Int. J. 2019, 22, 899-919. [CrossRef]

28. Oztemel, E.; Gursev, S. Literature review of Industry 4.0 and related technologies. J. Intell. Manuf. 2020, 31, 127-182. [CrossRef]

29. Bongomin, O.; Yemane, A.; Kembabazi, B.; Malanda, C.; Mwape, M.C.; Mpofu, N.S.; Tigalana, D. Industry 4.0 disruption and its neologisms in major industrial sectors: A state of the art. J. Eng. 2020, 2020, 8090521. [CrossRef] 
30. Melville, N.P.; Robert, L. The generative fourth industrial revolution: Features, affordances, and implications. Afford. Implic. 2020. [CrossRef]

31. Oesterreich, T.; Schuir, J.; Teuteberg, F. The Emperor's new clothes or an enduring IT fashion? Analyzing the lifecycle of industry 4.0 through the lens of management fashion theory. Sustainability 2020, 12, 8828. [CrossRef]

32. Madsen, D.Ø.; Berg, T.; Veen Hansen, E.; Ekeland Solberg, S. Close encounters of the 4th kind? An exploration of the state of industry 4.0 in Norway. Int. J. Manag. Concepts Philos. 2021, 14, 168-192. [CrossRef]

33. Dastbaz, M. Industry 4.0 (i4.0): The hype, the reality, and the challenges ahead. In Industry 4.0 and Engineering for a Sustainable Future; Dastbaz, M., Cochrane, P., Eds.; Springer International Publishing: Cham, Switzerland, 2019; pp. 1-11. [CrossRef]

34. Reischauer, G. Industry 4.0 as policy-driven discourse to institutionalize innovation systems in manufacturing. Technol. Forecast. Soc. Change 2018, 132, 26-33. [CrossRef]

35. Piccarozzi, M.; Aquilani, B.; Gatti, C. Industry 4.0 in management studies: A systematic literature review. Sustainability 2018, 10, 3821. [CrossRef]

36. Grønseth, B.O.; Madsen, D.Ø. Industry 4.0. In Encyclopedia of Tourism Management and Marketing; Buhalis, D., Ed.; Edward Elgar Publishing: Cheltenham, UK, 2022.

37. Fox, S. Irresponsible research and innovation? Applying findings from neuroscience to analysis of unsustainable hype cycles. Sustainability 2018, 10, 3472. [CrossRef]

38. Sudrajat, A.; Indartono, S. Impact and criticism of global capitalism in the industrial era 4.0. Adv. Soc. Sci. Educ. Hum. Res. 2019, 323, 200-206.

39. Badri, A.; Boudreau-Trudel, B.; Souissi, A.S. Occupational health and safety in the industry 4.0 era: A cause for major concern? Saf. Sci. 2018, 109, 403-411. [CrossRef]

40. Kravchenko, A.; Kyzymenko, I. The forth industrial revolution: New paradigm of society development or posthumanist manifesto. Philos. Cosmol. 2019, 22, 120-128. [CrossRef]

41. Lasi, H.; Fettke, P.; Kemper, H.-G.; Feld, T.; Hoffmann, M. Industry 4.0. Bus. Inf. Syst. Eng. 2014, 6, 239-242. [CrossRef]

42. Doyle-Kent, M.; Kopacek, P. Industry 5.0: Is the manufacturing industry on the cusp of a new revolution? Adv. Mech. Eng. 2020, 432-441. [CrossRef]

43. Østergaard, E.H. Welcome to Industry 5.0. Retrieved Febr. 2018, 5, 2020.

44. Demir, K.; Cicibas, H. Industry 5.0 and a critique of industry 4.0. In Proceedings of the 4th International Management Information Systems Conference, Istanbul, Turkey, 17-20 October 2017; pp. 17-20.

45. Haleem, A.; Javaid, M. Industry 5.0 and its expected applications in medical field. Curr. Med. Res. Pr. 2019, 9, 167-169. [CrossRef]

46. Haleem, A.; Javaid, M. Industry 5.0 and its applications in orthopaedics. J. Clin. Orthop. Trauma 2019, 10, 807-808. [CrossRef] [PubMed]

47. Skobelev, P.; Borovik, S.Y. On the way from Industry 4.0 to Industry 5.0: From digital manufacturing to digital society. Industry $4.02017,2,307-311$.

48. European Commission. Industry 5.0: Human-Centric, Sustainable and Resilient; European Commission, Directorate-General for Research and Innovation: Luxembourg, 2021.

49. Benders, J.; Verlaar, S. Lifting parts: Putting conceptual insights into practice. Int. J. Oper. Prod. Manag. 2003, 23, 757-774. [CrossRef]

50. Braam, G.; Benders, J.; Heusinkveld, S. The balanced scorecard in the Netherlands: An analysis of its evolution using print-media indicators. J. Organ. Change Manag. 2007, 20, 866-879. [CrossRef]

51. Benders, J.; Van Veen, K. What's in a fashion? Interpretative viability and management fashions. Organization 2001, 8, 33-53. [CrossRef]

52. Giroux, H. 'It was such a handy term': Management fashions and pragmatic ambiguity. J. Manag. Stud. 2006, 43, 1227-1260. [CrossRef]

53. Mertens, P.; Wiener, M. Riding the digitalization wave: Toward a sustainable nomenclature in Wirtschaftsinformatik. Bus. Inf. Syst. Eng. 2018, 60, 367-372. [CrossRef]

54. Moeuf, A.; Pellerin, R.; Lamouri, S.; Tamayo, S.; Barbaray, R. The industrial management of SMEs in the era of Industry 4.0. Int. J. Prod. Res. 2018, 56, 1118-1136. [CrossRef]

55. Pereira, A.C.; Romero, F. A review of the meanings and the implications of the industry 4.0 concept. Proc. Manuf. 2017, 13, 1206-1214. [CrossRef]

56. Frederico, G. From supply chain 4.0 to supply chain 5.0: Findings from a systematic literature review and research directions. Logistics 2021, 5, 49. [CrossRef]

57. Pillai, S.G.; Haldorai, K.; Seo, W.S.; Kim, W.G. COVID-19 and hospitality 5.0: Redefining hospitality operations. Int. J. Hosp. Manag. 2021, 94, 102869. [CrossRef]

58. Kopp, R.; Howaldt, J.; Schultze, J. Why industry 4.0 needs workplace innovation: A critical look at the German debate on advanced manufacturing. Eur. J. Work. Innov. 2016, 2. [CrossRef]

59. Longo, F.; Padovano, A.; Umbrello, S. Value-oriented and ethical technology engineering in industry 5.0: A human-centric perspective for the design of the factory of the future. Appl. Sci. 2020, 10, 4182. [CrossRef]

60. Johansson, J.; Abrahamsson, L.; Kåreborn, B.B.; Fältholm, Y.; Grane, C.; Wykowska, A. Work and organization in a digital industrial context. Manag. Rev. 2017, 28, 281-297. [CrossRef] 
61. Yordanova, K. The Curious Case of Industry 5.0. Available online: https:/ / www.law.kuleuven.be/citip/blog/the-curious-caseof-industry-5-0/ (accessed on 15 September 2021).

62. Ellegaard, O.; Wallin, J.A. The bibliometric analysis of scholarly production: How great is the impact? Science 2015, 105, 1809-1831. [CrossRef] [PubMed]

63. Donthu, N.; Kumar, S.; Mukherjee, D.; Pandey, N.; Lim, W.M. How to conduct a bibliometric analysis: An overview and guidelines. J. Bus. Res. 2021, 133, 285-296. [CrossRef]

64. Zupic, I.; Čater, T. Bibliometric methods in management and organization. Organ. Res. Methods 2014, 18, 429-472. [CrossRef]

65. Strang, D.; Wittrock, C. Methods for the study of management ideas. In Oxford Handbook of Management Ideas; Sturdy, A., Heusinkveld, S., Rey, T., Strang, D., Eds.; Oxford University Press: Oxford, UK, 2019; pp. 86-103.

66. Benders, J.; Nijholt, J.; Heusinkveld, S. Using print media indicators in management fashion research. Qual. Quant. 2007, 41, 815-829. [CrossRef]

67. Clark, T. The fashion of management fashion: A surge too far? Organization 2004, 11, 297-306. [CrossRef]

68. Cobo, M.J.; Lopez-Herrera, A.G.; Herrera-Viedma, E.; Herrera, F. An approach for detecting, quantifying, and visualizing the evolution of a research field: A practical application to the Fuzzy Sets Theory field. J. Inf. 2011, 5, 146-166. [CrossRef]

69. Balstad, M.T.; Berg, T. A long-term bibliometric analysis of journals influencing management accounting and control research. J. Manag. Control 2020, 30, 357-380. [CrossRef]

70. Buer, S.-V.; Strandhagen, J.O.; Chan, F.T.S. The link between industry 4.0 and lean manufacturing: Mapping current research and establishing a research agenda. Int. J. Prod. Res. 2018, 56, 2924-2940. [CrossRef]

71. Liao, Y.; Deschamps, F.; De Loures, E.F.R.; Ramos, L.F.P. Past, present and future of industry 4.0-A systematic literature review and research agenda proposal. Int. J. Prod. Res. 2017, 55, 3609-3629. [CrossRef]

72. Huczynski, A. Portrayals of management fashions in contemporary management and organisational behavior textbooks. Int. J. Manag. Educ. 2011, 9, 61-75. [CrossRef]

73. Furusten, S. Popular Management Books—How They are Made and What They Mean for Organisations; Routledge: London, UK, 1999.

74. Engwall, L.; Wedlin, L. Business studies and management ideas. In Oxford Handbook of Management Ideas; Sturdy, A., Heusinkveld, S., Reay, T., Strang, D., Eds.; Oxford University Press: Oxford, UK, 2019.

75. Goodrum, A.A.; McCain, K.W.; Lawrence, S.; Giles, C.L. Scholarly publishing in the Internet age: A citation analysis of computer science literature. Inf. Process. Manag. 2001, 37, 661-675. [CrossRef]

76. Van Eck, N.J.; Waltman, L. Software survey: VOSviewer, a computer program for bibliometric mapping. Scientometrics 2009, 84, 523-538. [CrossRef]

77. Janik, A.; Ryszko, A. Mapping the field of Industry 4.0 based on bibliometric analysis. In Proceedings of the 32nd IBIMA Conference, Seville, Spain, 15-16 November 2018.

78. Abdel-Basset, M.; Manogaran, G.; Gamal, A.; Chang, V. A novel intelligent medical decision support model based on soft computing and IoT. IEEE Internet Things J. 2020, 7, 4160-4170. [CrossRef]

79. Bednar, P.; Welch, C. Socio-technical perspectives on smart working: Creating meaningful and sustainable systems. Inf. Syst. Front. 2020, 22, 281-298. [CrossRef]

80. Welfare, K.S.; Hallowell, M.R.; Shah, J.A.; Riek, L.D. Consider the human work experience when integrating robotics in the workplace. In Proceedings of the 2019 14th ACM/IEEE International Conference on Human-Robot Interaction (HRI), Daegu, Korea, 11-14 March 2019; Institute of Electrical and Electronics Engineers (IEEE): Piscataway, NJ, USA, 2019; pp. 75-84.

81. Wang, Y.; Cai, Z.; Zhan, Z.-H.; Zhao, B.; Tong, X.; Qi, L. Walrasian equilibrium-based multiobjective optimization for task allocation in mobile crowdsourcing. IEEE Trans. Comput. Soc. Syst. 2020, 7, 1033-1046. [CrossRef]

82. Madsen, D.Ø.; Slåtten, K. Social media and management fashions. Cogent Bus. Manag. 2015, 2, 1122256. [CrossRef]

83. Barros, M.; Rüling, C.-C. Business media. In The Oxford Handbook of Management Ideas; Sturdy, A., Heusinkveld, S., Reay, T., Strang, D., Eds.; Oxford University Press: Oxford, UK, 2019; pp. 195-215.

84. Piazza, A.; Abrahamson, E. Fads and fashions in management practices: Taking stock and looking forward. Int. J. Manag. Rev. 2020, 22, 264-286. [CrossRef]

85. Kieser, A. Rhetoric and myth in management fashion. Organization 1997, 4, 49-74. [CrossRef]

86. Zorn, T.; Collins, E. Is sustainability sustainable? Corporate social responsibility, sustainable business, and management fashion. In The Debate over Corporate Social Responsibility; Oxford University Press: New York, NY, USA, 2007; pp. 405-416.

87. Mitra, R. Sustainability and sustainable development. In The International Encyclopedia of Organizational Communication; Wiley: Hoboken, NJ, USA, 2016; pp. 1-10.

88. Madsen, D.Ø.; Stenheim, T. Is corporate social responsibility a management fashion in Norway? Some preliminary evidence. Eur. J. Bus. Res. 2014, 14, 87-99. [CrossRef]

89. Dantas, T.; De-Souza, E.; Destro, I.; Hammes, G.; Rodriguez, C.; Soares, S. How the combination of circular economy and industry 4.0 can contribute towards achieving the sustainable development goals. Sustain. Prod. Consum. 2021, 26, 213-227. [CrossRef]

90. Zengin, Y.; Naktiyok, S.; Kaygın, E.; Kavak, O.; Topçuoğlu, E. An investigation upon industry 4.0 and society 5.0 within the context of sustainable development goals. Sustainability 2021, 13, 2682. [CrossRef]

91. Stock, T.; Obenaus, M.; Kunz, S.; Kohl, H. Industry 4.0 as enabler for a sustainable development: A qualitative assessment of its ecological and social potential. Process. Saf. Environ. Prot. 2018, 118, 254-267. [CrossRef] 
92. Madsen, D.Ø.; Stenheim, T. Doing research on 'management fashions': Methodological challenges and opportunities. Probl. Perspect. Manag. 2013, 11, 68-76.

93. Carson, P.P.; Lanier, P.A.; Carson, K.D.; Birkenmeier, B.J. A historical perspective on fad adoption and abandonment. J. Manag. Hist. Arch. 1999, 5, 320-333. [CrossRef] 